\title{
Journal of the Canadian Historical Association Revue de la Société historique du Canada
}

\section{The Timeless African and the Versatile Indian in Seventeenth-Century Travelogues}

\section{Michel Duquet}

Volume 14, numéro 1, 2003

URI : https://id.erudit.org/iderudit/010318ar

DOI : https://doi.org/10.7202/010318ar

Aller au sommaire du numéro

Éditeur(s)

The Canadian Historical Association / La Société historique du Canada

ISSN

0847-4478 (imprimé)

1712-6274 (numérique)

Découvrir la revue

Citer cet article

Duquet, M. (2003). The Timeless African and the Versatile Indian in Seventeenth-Century Travelogues. Journal of the Canadian Historical Association / Revue de la Société historique du Canada, 14(1), 23-44. https://doi.org/10.7202/010318ar

\section{Résumé de l'article}

Déclenchée par la découverte de l'Amérique en 1492, la course aux empires marqua l'histoire du XVIIe siècle. C'est pendant cette période que le commerce sur la côte occidentale de l'Afrique connaît un essor important et que des explorateurs, des marchands, des colons et des missionnaires hollandais, français et anglais établissent des colonies de peuplement permanentes en Amérique du Nord. Ceux de ces aventuriers qui firent un récit de leurs voyages ont décrit en détail les aborigènes rencontrés outre-mer. Que ces carnets de bord soient l'oeuvre de Hollandais, de Français ou d'Anglais, ils projettent tous essentiellement les mêmes représentations de l'Africain et de l'Indien d'Amérique du Nord. Si les descriptions des peuples aborigènes africains sont continuellement tissées de commentaires désapprobateurs, celles des autochtones nord-américains sont par contre empreintes de sentimentalisme alliant compassion, critique et admiration. Une des causes profondes de ce contraste d'attitudes serait d'ordre environnemental : rebutés par le climat tropical de l'Afrique de l'Ouest qu'ils jugeaient inhospitalier et meurtrier, les Européens auraient été conséquemment peu réceptifs au choc des cultures. Toutefois, ils auraient appris à mieux connaître les sociétés autochtones de l'Amérique du Nord. Le présent article propose des explications à cette différence de perception et analyse le contexte dans lequel les images d’aborigènes africains et nord-américains ont été façonnées.
Tous droits réservés (C) The Canadian Historical Association/La Société historique du Canada, 2003
Ce document est protégé par la loi sur le droit d'auteur. L'utilisation des services d'Érudit (y compris la reproduction) est assujettie à sa politique d'utilisation que vous pouvez consulter en ligne.

https://apropos.erudit.org/fr/usagers/politique-dutilisation/ 


\title{
The Timeless African and the Versatile Indian in Seventeenth-Century Travelogues
}

\author{
MICHEL DUQUET
}

The Dutch, French, and English visitors to Africa and North America in the
seventeenth century have left us a treasure trove of writings of their travels. ${ }^{1}$ In spite of the multitude of studies which have skillfully brought to light the various agendas as well as the different images of the African and the North American found in these accounts, none have sought to combine these sources in order to give an explanation for the variations that exist in the portrayal of these natives on the two continents. A comparative examination of these chronicles reveals that the representation of the North American evolved in the course of the seventeenth century, while that of the African was more negative and remained static throughout the period in question. A priori, one could assume that this was a reasonable reaction by seventeenth century white European travelers who, particularly given the extreme cultural differences between themselves and black Africans, would have had a more favorable view of the North American Indian with whom he shared some physiological similarities. Yet racial prejudice was a nineteenth-century ideology that would not have been a tenet of European writers in the 1600s. Rather, it could be said that the different types of encounter, the contrasting environments of Africa and North America, and the opposite objectives of Europeans on the two continents were the root causes for the lesser and unchanging image of the African native.

The high death rates sustained by Europeans unable to resist diseases latent in the physical environment of Africa not only curtailed European ambitions there, but they also led to the construct of the African native as the quintessential and permanent embodiment of savagery in comparison with European civility in that genre of literature. The few European travelers who ventured forth into Africa simply perpetuated fallacies on Africans and Africa based on old myths. European writers of travelogues were thus able to explain the socalled reluctance of European travelers to visit, settle, and explore the Dark Continent. In contrast, the paradise-like environment of temperate North

1 The author would like to thank professor Eric Jenkins, under whose supervision this paper was written, as well as the anonymous assessors of this journal for their comments on previous drafts of this article. 
America (even in New France, at least in the summer) and the seemingly hospitable natives initially produced a much friendlier portrayal of the North American.

The preferential treatment accorded to North America Indians relative to African natives was primarily expressed in biblical terms, because religion occupied such a central role in defining European culture expressing personal identity. The gist of the argument was that although both continents had strayed from God's grace, Africans did so willfully while North Americans had erred by omission rather than by design. The message here was clear: Africa remained stubbornly outside the grasp of European colonizers and missionaries; North America seemed destined to be reunited with God's grace under European guidance. Finally, the African was further disadvantaged by his skin color since it was associated with existing aesthetic prejudices regarding the color black in Europe, while North American Indians did not have to overcome this cultural obstacle.

The native did not merely act as a point of reference for these explorers, colonizers, missionaries, and travelers expressing particular European worldviews and their objectives abroad in their writings. On the contrary, the different (yet at times similar) images of the African and the North American natives, and, more importantly, the unchanging nature of the former and the evolving character of the latter, were illustrations of the continued ignorance of Africa and Africans by Europeans and their growing familiarity with North America and its inhabitants.

European writers were clearly influenced by what they experienced in their description of natives. While the majority of European chroniclers initially depicted North America as a nirvana and their hospitable inhabitants in the most glowing terms, they soon began to focus on the savagery of the American Indian and the incompatibility of native customs with European civilization when natives did not cooperate eagerly in commercial enterprises or violently opposed European settlement. In contrast, the lack of knowledge about Africa as a result of the minimal and ephemeral presence of Europeans there facilitated the durability of the beastly African throughout the seventeenth century independently of any potential ideological development that Europe underwent during that period.

Yet, that is not to say that the image of the native was not part and parcel of European conception of their specific culture whether it be French, Dutch, or English. Nor does this paper negate the idea that representations of the native were dictated partly by the claims of the rediscovery of North America. Indeed, the need to encourage settlement, the right to conduct commerce anywhere it pleased Europeans, the justification for the aggressive policy of religious conversion of natives, and their expropriation from ancestral lands demanded that the natives be described as inferiors to Europeans. But it remains that the 


\section{THE TIMELESS AFRICAN AND THE VERSATILE INDIAN IN SEVENTEENTH-CENTURY TRAVELOGUES}

evolving - whether negative or positive - description of native mores on the North American continent demanded a certain knowledge of them, an edification that was unattainable to Europeans in Africa. As a result, the African remained shrouded in his savagery, while the native in North America went through various images in the seventeenth-centuy travel accounts covered in this study. ${ }^{2}$

Africa, unlike America, had been known in Europe for over a millennium by the 1600s. According to Herodotus (whose writings the majority of writers of travelogues in the seventeenth century were acquainted with), Phoenicians were the first to have visited the coast of Africa some 600 years before the birth of Christ. ${ }^{3}$ Hakluyt wrote in mid-sixteenth century that the African continent was one of the three parts of the world "knowen in old time." 4 By and large, the image of Africa and the African in Europe had, by the early modern period, been shaped by a Christian ideology and/or by hypotheses found in the classics and preceding travel literature. William Cohen states that Pliny's Natural

2 A note on the sources utilized. The manuscripts utilized in this article cover the whole of the seventeenth century and were written by French, Dutch, and English writers. Although travelers from these European countries visited both Africa and North America in the seventeenth century, none of these travelogues offer a comparison between the African and North American native, an omission that speaks volumes on the continued general lack of knowledge on Africa and of the mental partition that European travelers had made between the two continents. In addition, religious sources were kept to a minimum, given that missions on the west coast of Africa were almost non-existent throughout this period, and this made comparisons between the two continents based on that specific literature almost impossible. Furthermore, it may be wise at this point to qualify the term "European" when talking of the conception of the African that will be used in this paper. One must keep in mind that travel narratives were accessible only to very few Europeans whose literary skills made that group an elite in a population that was overwhelmingly illiterate. In addition, the views expressed by these writers were those of men which did not take into account the opinion of the majority - that of women. Yet, the word "European" is not totally misleading since travel relations and ancient texts were, for all intents and purpose, the only means by which European could learn something (however biased or erroneous) about Africa because physical travel to that continent in the seventeenth century and before was the experience of only a minute number of Europeans. Moreover, the adaptation of travel stories into plays by popular European novelists who sought to profit from the huge popularity of travel accounts in the second half of the $1600 \mathrm{~s}$, helped give tales of Africa a wider audience and thereby influenced and molded European images of the "dark" continent. On the lasting popularity of travelogues in the seventeenth century and beyond see Percy Adams, Travelers and Travel Liars 1660-1880. Berkeley: University of California Press, 1962), 224. He writes that the majority of the great novelists in the eighteenth century - including Defoe and Stern - responded to the trend in eyewitness accounts and published their own travels.

3 Anecdote found in Roger Mercier, L'Afrique noire dans la littérature française: Les premières images XVIIe-XVIIIe siècles (Dakar: Presses de 1'Université de Dakar, 1962), 8.

4 Richard Hakluyt. The Principal Navigations, Traffiques \& Discoveries of the English Nations ... 12 Volumes (Glasgow: J. Maclehose, 1903-05), 6:144 
History, written in the third century, went through forty-six editions between 1450 and 1550. ${ }^{5}$ This reliance on templates borrowed from antiquity helped reproduce certain archetypal myths about that part of the world including that of the headless African that found its way in the Cosmologie Universelle published by Francis' 1st geographer André Thévet in $1575 .^{6}$

One of the most enduring European conceptions about Africa was that of the biblical curse incurred by the indigenous population. Because the color of Africans offended their aesthetic taste, Europeans felt that blackness could not be anything but an affliction. ${ }^{7}$ More specifically, the colored misfortune of Africans was expressed in terms of a blight placed on Ham and his progeny because he had shamed his father Noah. Writers of travel accounts took up the theme of God's terminal execration of the black population in the seventeenth century. Jobson's view on the population of Africa was that "undoubtedly these people originally sprung from the race of Canaan, the son of Ham." 8 The idea of accursed Africans and of the whole African continent was a common mantra in books describing voyages to that part of the world. It was repeated throughout Claude Jannequin's recounting of his trip where Africa was characterized either as a "cursed country," a "cursed land," or a "cursed nation." 9 Worse still, the blame for the curse was strictly attributed to the natives themselves. Nicolas Villault argued that while Europeans prayed to the right (white) God, Africans worshipped a black one who happened to be the devil himself. ${ }^{10}$

The African also became the counterpart to the feared medieval "wildeman" who lived outside of Christian norms and the framework of Christian society in Europe. The blackness of Africans seemed especially suited to embody medieval notions of savagery, evilness, and monstrosity. Many accounts of Africa in the seventeenth century focussed on native skin color, thereby reinforcing the association between the continent and blackness. In the process of creating what Emily Partels calls "images of evil-blackened-by-sin Africans," 11 Europeans wrote about Africans as if the latter wished that a white

5 William Cohen, The French Encounter with Africans: White Responses to Blacks, 1530-1880 (Bloomington: Indiana University Press, 1980), 2.

6 Ibid., 5.

7 The Sixteenth Century Oxford English Dictionary describes the word black as: "Deeply stained with dirt; soiled, dirty... Having dark or deadly purposes, sinister... Foul, iniquitous, atrocious, horrible, wicked. Indicating disgrace, censure, liability to punishment, etc..."

8 Richard Jobson. The Golden Trade: or a Discovery of the River Gambra (New York: Da Capo Press, 1968), 52.

9 Claude Jannequin. Voyage de Lybie au Royaume de Sénéga (Paris: C. Rouillard, 1643), 44, 56, 60.

10 Nicolas Villault, Sieur de Bellefond. Relations des Costes d'Afrique Appelées Guinée (Paris: D. Thierry, 1669), 261.

11 Emily C. Bartels, "Othello and Africa: Postcolonialism Reconsidered," William and Mary Quarterly S3, v.54 (January 1997), 53. 


\section{THE TIMELESS AFRICAN AND THE VERSATILE INDIAN IN SEVENTEENTH-CENTURY TRAVELOGUES}

God (represented by European travelers, merchants, and would be colonizers) would come along to relieve them of their paganism and wickedness.

The relocation of Christian myths to Africa included that of European witches of the middle ages who were replaced by native women in travelogues. Jennifer Morgan writes that medieval tales of wild women whose breasts dragged on the ground as they walked were readjusted to fit African women in travel narratives. ${ }^{12}$ Pieter de Marees, for one, expressed being repulsed by the ugliness of women in Africa especially old ones whose "long breasts look like old pigs' bladders." 13 The Dutch explorer also wrote about women in witchlike terms, who breast-fed their infants "by letting it [their breast] hang over their shoulder to be sucked." 14

The description of African women in hideous terms reminiscent of medieval European witches bent on wrecking havoc on Christian societies was also complemented by another Christian myth of the wild woman that was transplanted in Africa - that of the seductress. ${ }^{15}$ While European witches disguised themselves with youth and beauty in order to seduce young mortal men in the middle ages, African women, equally cursed with sagging breasts and ugliness, went to great lengths to fulfill their craving for white men. ${ }^{16}$ Jean Barbot seemed to be well acquainted with this myth when he claimed that white men were more pleasing to African women than African men, and "few of them [African women] will refuse the final favor if offered the most trifling gift" (which begs the question of why European men had to offer gifts in the first place). ${ }^{17}$ In another account, we find that African women - under the pretext of trade - "debauch our Whites". ${ }^{18}$ In the end, the ethnocentric view of the anomaly of the color of Africans led to the transplantation of the medieval evilness of witches and wildmen to Africa in seventeenth century travel relations. And in the process, Africa became the perfect Other (and lesser) of Europe.

European travelers who wrote about the cursed Africa exported other existing medieval beliefs to that continent. The myth of the calamity of Ham and his

12 Jennifer Morgan, "Some Could Suckle: Male Travelers, Female Bodies, and the Gendering of Racial Ideology, 1500-1770," William and Mary Quarterly S3, v.54 (January 1997), 170.

13 Pieter de Marees, Description and Historical Account of the Gold Coast of Guinea (1602). (Oxford: Oxford University Press, 1987), 180.

14 Ibid. p.24. The "abnormality" of African women's breasts was tied to the myth of the witch in Europe since the middle ages. These folkloric creatures were said to be equally burdened by elongated breasts; a sure sign of their witchiness.

15 The racialist discourse of seventeenth-century writers of voyage accounts also incorporated European notions of gender differences and power structure where men dominated society.

16 Morgan, "Some Could Suckle". 170.

17 Jean Barbot, Barbot on Guinea: The Writings of Jean Barbot on West Africa 1678-1712 (London: Hakluyt Society, 1992), 85.

18 Michel Jajolet de La Courbe, Premier Voyage à la Côte d'Afrique en 1685, publié avec une carte de Deslisle et une Introduction par P. Cultru (Utrecht: Ches A. Schouten, 1705), 28. 
descendants had been one of the major arguments used by the European elite to justify the nature of God-given social orders in the middle ages. This conception of society where nobles were supposed to be the descendants of Noah's oldest son Japeth, the clerks from his middle son Sham, and the serfs from the youngest Ham, ${ }^{19}$ was reinterpreted and applied to the world at large in seventeenth-century travelogues. In this scheme of things, Europe acquired the place of privilege in the world that the nobles enjoyed in European societies, Asia was decreed to be Sham's offspring and that inferior to Europeans but superior to Africa, while Africa was the inheritor of Ham and his curse and thus placed lowest on the hierarchical scale of continents. ${ }^{20}$ Continents and colors were thus affixed permanent roles in the world-according-to-Europe. Hence, the poorer representations of the African can undoubtedly be traced to the reliance of these writers on ancient literature and European myths dating from the middle ages. This insight, though, does not explain the repetition of these same images for the next hundred years despite a greater presence on the African west coast in the seventeenth century by Dutch, French, and English travelers. And here we touch upon the crux of the argument that the type of encounters that took place in Africa was the definite characteristic which determined not only the image of the African natives in travel accounts, but also its durability. Both of these issues will be discussed at length after having compared what was happening in North America at the time of contact early in the century.

On the other side of the Atlantic, both the French and British (and the Dutch in the first half of the 1600s) entered the imperial race in the Western Hemisphere that had seen the occupation of large parts of Central and South America by the Portuguese and the Spanish since the sixteenth century. The "rediscovery" of North America proved to be the first step toward the legitimization of the colonizing objectives of France and Britain in the New World. Few Europeans questioned their rights of possession over North America at the time. Pierre Boucher was expressing a widespread sentiment in the literature of the day when he wrote that the North American territory was idyllic "except that it needed inhabitants." 21 This notion of America being uninhabited (which in itself is highly revealing of Europeans' low opinion of the uncivilized Other at the time) was an expression of the feeling of predominance

19 William Cohen, The French Encounter with Africans: White Responses to Blacks, 1530-1880. (Bloomington: Indiana University Press, 1980), 11.

20 Henri Baudet, Paradise on Earth: Some Thoughts on European Images of Non-European Man (London: Yale University Press, 1965), 17.

21 Pierre Boucher, Histoire véritable et naturelle de la Nouvelle-France, (Boucherville: Société Historique de Boucherville, 1964), 6. Although this section on North America deals only with the French and British, the term European seems appropriate because natives of Europe thought themselves as belonging to the same cultural group. See David Eltis. "Europeans and the Rise and Fall of African Slavery in the Americas: An Interpretation," American Historical Review v.98, Issue 5 (December 1993), 1400. 


\section{THE TIMELESS AFRICAN AND THE VERSATILE INDIAN IN SEVENTEENTH-CENTURY TRAVELOGUES}

that Europeans had at the time. The inferiorisation of the Indian was constructed in a number of ways. Native Americans were often described as surprisingly "very tall, erect, strong, [and] well proportioned," as if Europeans did not expect these physical qualities amongst people outside of Europe. ${ }^{22}$ In addition, the Europeans who wrote of their experience in America often noticed the seeming whiteness of local natives. This appreciation of North Americans' skin color was in fact a covert means by which these Europeans reinforced their difference from the native Other. When Boucher wrote that "children are born as white as the French", and when Martin Pringe reported that although natives were of various complexions from the "tawny" to the "swarthy brown," they darkened themselves accidentally "by greasing or sunning themselves," the implication was that the natives degenerated into something unEuropean, that they remained alien to the writers and their compatriots. ${ }^{23}$

Moreover, Europeans depicted natives as being irresponsible children who needed direction. Although the idolatry, paganism, anthropophagy, and savagery of natives were recorded in early travel accounts to America in the early 1600s, this deplorable behavior was portrayed as being demonstrations of naive children who did not know right from wrong. John Smith could thus deplore the "satanic" practices of Indians in Virginia and yet attenuate their guilt by stating that "these poore soules sacrifice themselves to the Divell, [on account of] not knowing their creator." 24 Smith's contemporary Champlain went even further in condoning the savage practices of natives. He wrote that cannibalism was somewhat excusable because "all these people suffer so much that they have to resort to eating one another." 25 Thus, a seventeenth-century reader of travel literature could easily have envisioned a native that was desperate to receive the help of the civilizing European explorer. Such was the thought behind the design of the seal of the British Company Massachusetts Bay in 1629 where an Indian is posturing in a manner that begs the image of asking the English to "come and help us." 26

Writers of travel relations also portrayed North American Indians as longlost children of God who could be brought back into the fold by Europeans who had a privileged role to play in a Christian civilized world. This back-in-time

22 Samuel de Champlain, Des sauvages ou voyages de Sieur de Champlain aux Indes occidentales (1603) (Montréal: Éditions TYPO, 1993), 32.

23 Boucher, Histoire véritable et naturelle, 1964, 92. Martin Pringe in Alison M. and David B. Quinn (eds), The English New England Voyages 1602-1608 (Cambridge: Cambridge University Press, 1983), 221.

24 In Philip Barbour (ed). The Complete Works of John Smith (1580-1631) in Three Volumes (Chapel Hill: University of North Carolina Press, 1986), 172.

25 Champlain, Des sauvages ou voyages de Sieur de Champlain, 105.

26 Anthony Pagden, Lords of All the World: Ideologies of Empire in Spain, Britain, France c.1500-c.1800 (London: Yale University Press, 1995), 88. 
travel theory was expressed through the association made between ancient civilizations and Indian populations in numerous travel accounts. The Jesuit priest Jean de Brébeuf thought that they were the descendants of ancient Romans while Louis Hennepin argued that "Indians were of Jewish origins" by pointing out that they anointed themselves, believed in dreams, and lamented their dead in Jewish-like fashion. ${ }^{27}$ The assumption was that local natives only needed to regain their knowledge of God (with the help of Europeans, of course) to become what was described as civilized. Louis Lahontan advocated that "let us believe that they are, like ourselves, descendants from Adam and Eve," after he noticed that their religion always had "something related to the Ancient Testament." 28 The cultural gap between Europeans and natives who had forgotten their Christian roots was conveniently minimized in this presumption that North Americans were the descendants of ancient European peoples. The Catholic priest Gabriel Sagard was of the opinion that "if they were Christian, God would be happy to stay with these families." 29 And if the indigenous population of America had lost its knowledge of God, it was entirely possible that Europeans could just as easily have forgotten about the continent and its inhabitants through the ages. The first wave of Europeans visitors to North America in the 1600 s were therefore able to rationalize their centuries-old belief in Christianity, reaffirm the authority of ancient philosophers on whom some of their claims of cultural arrogance rested (namely, the preeminence of a European literate culture over that of a native oral tradition), and gain primacy in their dealings with unenlightened native populations.

Lost in the discourse of early seventeenth-century travel literature was that the ardent desire of colonists to convert the forsaken native was often motivated by greed. Very few writers were as forthright about the ambitions of Europeans arriving in the new world as Edward Winslow was when he wrote in 1624, that "America was a place where religion and profit jumped together." 30 The motivation of Europeans explains the initial description of natives in the best possible light, because their conversion and acculturation was part and parcel of European colonization there. In Africa, conversely, the inhospitable environment prevented European permanent settlement and shaped the negative images of that continent and its inhabitants in travelogues throughout the

27 Jean de Brébeuf, Jean de Brébeuf (Montréal: Fides, 1958), 32. Louis Hennepin. Description of Louisiana, translated by John Gimary Shea (Ann Harbor: University of Michigan Microfilms, 1966), 280.

28 Louis Armand Lahontan, Oeuvres complètes (Montréal: Les Presses de l'Université de Montréal, 1990), 631.

29 Gabriel Sagard, Le grand voyage du pays des Hurons situé en l'Amérique. Édition critique de Jack Warwick (Montréal: Les Presses de l’Université de Montréal, 1998), 191.

30 Anthony Pagden, The Fall of Natural Man: The American Indian and the Origins of Comparative Ethnology (Cambridge: Cambridge University Press, 1979), 34. 


\section{THE TIMELESS AFRICAN AND THE VERSATILE INDIAN IN SEVENTEENTH-CENTURY TRAVELOGUES}

seventeenth century (although a smitten of accounts paint some natives who cooperated with merchants in a better light, as we will see). The situation facing Europeans arriving in Africa and North America at the dawn of the 1600s could not have been more polarized. On the one side, a continent known for centuries whose population still remained outside of the realm of Europe. On the other side, uncivilized yet less distinct natives who seemed opened to join the happy Christian family of Europe who sought to do just that.

A survey of works related to regions outside of Europe published in the sixteenth and seventeenth centuries shows that books on Africa accounted for only eight percent of that total. ${ }^{31}$ At first glance, this statistic might suggest that the reputed European aversion to the blackness of natives there was enough to prevent scores of Europeans from visiting and/or writing about Africa. Those numbers could also support the idea that the monstrosities reported in ancients texts reproduced in seventeenth-century voyages could have acted as deterrents to evangelization efforts by European Christians missionaries who were extremely busy doing just that in other parts of the world at the time. ${ }^{32}$ Finally, the low percentage of books about Africa could have been representative of the supposed reluctance of Europeans to settle on the Dark Continent, with the portrayal of Africans in contemporary accounts itself sustaining the unwillingness of white Europeans to settle amongst so-called black savages.

Instead, however, Africa's lack of popularity was based on more practical reasons. An insurmountable obstacle stood in the way of colonization on the west coast of Africa (and the conversion of its population) by secular and religious Europeans. And, in turn, this hurdle nurtured the myth of the dark, mysterious, forbidding Africa in which blackness played such a defining role. The fundamental reason for the small number of Europeans in Africa, and the meager interest (if the low number of published travel accounts related to Africa in comparison with that of other parts of the world can be used as a

31 Cohen, The French Encounter with Africans, 7. The author adds that the unpopularity of Africa in Europe was also reflected by the lack of interest shown in geographical works. Only 38 of the 675 books on geography published in Europe in the seventeenth century (other than those describing various regions within the European continent) depicted the West coast or the interior of the sub-Saharan Africa), p.6. Geoffroy Atkinson confirms that lack of interest in, and continued ignorance of, Africa in regards to France. He estimates that a measly five books depicted the geography of Africa out of the 250 geographic works published in that country between 1480 and 1690. See Geoffroy Atkinson, Les nouveaux horizons de la Renaissance française (Paris: Librairie Édouard Campion, 1935), 10-11.

32 Although most who wrote travel literature in the seventeenth century actually visited the places they described to the reader, this was not always the case, nor was it always made clear in the said "travel" literature. The issue of real versus imaginary voyage is pertinent in the case of Africa and the impact of borrowing existing literature to describe Africa and its inhabitants will be discussed later on in the essay. 
factual barometer) for that continent, was the high death rate suffered by white travelers to that continent. African diseases were nearly as dangerous to Europeans as European diseases were to Amerindians. Most seventeenthcentury Europeans would have been aware of the reputation that Africa gained as a white man's grave. Indeed, between 25 percent to 50 percent of all Portuguese merchants who traded with Africans in the fifteenth century never came back. ${ }^{33}$ The situation did not get any better in the seventeenth century. Only one in ten men employed by the British-owned Royal African Company could expect to be discharged at the end of his seven year term with a full six in ten employees dying in their first year there in the late 1600s. ${ }^{34}$

Consequently, a reading of these travelogues should be done while taking into account the reality facing the Europeans writing them and their objectives there. Terms such as savagery, evilness, monstrosity, and nakedness are idioms that were used interchangeably to describe not only the customs of local natives per se, but also to characterize the trading mannerisms of various African groups. Since trade was the first and only motivation for European presence there (because tropical diseases prevented their colonization of the coast and the large-scale conversion of its inhabitants), it is not surprising to find out that illustrations of local customs were largely done in the context of commercial transactions. Africans who refused to trade with, insulted or assaulted Europeans, were said to be either "cruel or evil," a "black ... wicked and faithless people," "monsters," or "wild savage blacks." 35

Lastly, the fiercer the competition amongst Europeans in Africa over scarce resources, and the higher the cost and peculiarity of African methods of doing business, the longer and oftener European medieval pejorative stereotypes of Africans were perpetuated in seventeenth-century voyage accounts. Some Africans (although the reader would be hard-pressed to delineate one from the other since they were all afflicted by blackness in these accounts) were deemed to possess an inherent badness. In the Dutch Pieter de Marees' writings, for example, Africans are accused of the worst character defects only because they dared to trade with the Portuguese. ${ }^{36}$ In addition, European merchants complained endlessly over the cost of the added expense of ridiculous practices, gift-giving preambles and, more important, the adulteration of gold by savage

33 Philip D. Curtin, The Rise and Fall of the Plantation Complex (New York: Cambridge University Press, 1990), 39-40.

34 Ibid.

35 de Marees, Description and Historical Account, 12. John Ogilby. An Accurate Description of Africa (London: Tho. Johnson, 1690), 378. N.M. Penzer (ed). The World Encompassed and Analogous Documents Concerning Sir Francis Drake's Circumnavigation of the World (New York: Cooper Square Publishers Inc., 1969), 21. Barbot, Barbot on Guinea, 176.

de Marees, Description and Historical Account, 82. 


\section{THE TIMELESS AFRICAN AND THE VERSATILE INDIAN IN SEVENTEENTH-CENTURY TRAVELOGUES}

Africans that made commerce a much lesser profitable enterprise than first envisioned. ${ }^{37}$ The repulsion propagated by travelers who wrote after their passage in Africa was dictated to a great extent by the harsh environmental factors facing them upon their arrival in Africa. And, in turn, the difficulties encountered by European visitors to Africa when conducting business transactions in an inhospitable environment with difficult individuals whose language and customs they understood little, ensured the numbing repetition of dreadful illustrations of the African in travel accounts during that period.

The positive treatment given to natives in accounts of early seventeenthcentury voyages made to North America might lead to the assumption that the inhabitants of this continent benefited (comparatively speaking) from the curse of the Negro that plagued the Africans in the travel literature at the time. As we have seen, unlike the Negro who it was thought could not change the color of his skin anymore than the leopard could change its spots, the North American Indian appeared to temporarily induce his relatively dark complexion. ${ }^{38}$ The savagery of the American native could thus be seen as being a non-permanent condition. In addition, while Africans willfully worshipped the Devil, Indians were said to be under the influence of the Devil unwillingly. Furthermore, although anthropophagy was described as second nature to Africans in general, the act of eating their enemies and companions alike carried out by some Indians was often pardoned by European writers who related the extenuating circumstances or reasoning behind the cannibalistic practices of its participants. Yet, a thorough examination of seventeenth-century travelogues tells us that the different representations of African and North American natives was a reflection of the contrasting conditions that prevailed for European visitors to America and Africa. The newly-discovered disease-free (for arriving White travelers) American soil had a similar climate to that of Europe and was seemingly inhabited by a non-threatening population who welcomed them, both of which inspired writers to portray America and its inhabitants in a positive fashion.

Just as important in the image of the agreeable native was the fact that Europeans were not self sufficient and depended heavily (at least in the first few decades in British-held areas and much longer in New France) on the native population in order to survive. Settlers coming to North America in the early 1600s envisioned their colonial undertaking in providentialist, imperialist terms. For instance, the puritan William Bradford thought that the epidemics that decimated certain native tribes was a miracle that God had performed to "prove the rightful

37 Barbot, Barbot on Guinea, 349.

38 Jordan Winthrop, White over Black (Chapel Hill: University of North Carolina Press, 1968), 15. Here the author quotes from the bible (Jeremiah 13:23). 
ownership of land in North West Virginia."39 John Smith was also in the same frame of mind when he wrote, "with God's gracious assistance ... will our nation enjoy a country ... very profitable for commerce." 40 Notwithstanding the great confidence showed by early colonists in their providential mission, it was the native population rather than God who provided them with the help they needed to gain a permanent foothold on the continent. The same John Smith admitted as much in 1608 when he noted "the Indians thinking us neare famished, with careless kindness offer'd us little pieces of bread."41

The American native's willingness to accept the presence of European settlers on their land was another essential component in the construct of the optimistic image of the North American Indian in travel chronicles. Europeans arriving on the continent in the 1600s could not arbitrarily impose their will on the inhabitants of the New World in spite of their clear technological advantage in firepower. The huge demographic disadvantage of Europeans in North America meant that colonists were forced to be more accepting of the Indian than visiting merchants were of the African. The autonomy of certain indigenous peoples was a reality. Champlain acknowledged his powerlessness and his frustration over his inability to explore the Lac Saint-Jean area. He wrote that although he strongly desired to do so, "I could not go [there] without the Indians who did not want me to go."42 The continued dependence on natives and the need to form military alliances (like the long-standing association between the French with Algonquian tribes against the five Iroquois nations) meant that the image of the American Indian was not imbued with notions of separation and degradation that was common in representations of the "black savage." Not surprisingly, the precarious situation of settlers in North America in early seventeenth century persuaded writers of travel accounts to regularly expressed the desire to cooperate with natives, to "use the people with as great kindness as we could devise."43

Moreover, internal developments in France and England also contributed to the idealization of North America and its populations in travel accounts at the

39 In Gilles Thérien (directeur). Les figures de l'Indien (Montréal: Service des Publications de l’Université du Québec à Montréal, 1988), 1999.

40 Barbour (ed), The Complete Works of John Smith, 97.

41 Ibid., 35. Smith makes light of their situation in that year and well into the 1630s. Nevertheless, settlers were in a very precarious situation most of the time and often were in dire straights at the onset of European settlement in North America. Various contemporary authors reported that starving colonists often abandoned European settlements to join native bands while others even resorted to eat unearthened cadavers. For more on this issue see Mary C. Fuller, Voyages in Print: English Travel to America, 1576-1624 (Cambridge: Cambridge University Press, 1995), and Gary B. Nash, Red, White, and Black: The People of Early North America (3rd Edition) (New Jersey: Prentice Hall, 1992).

42 de Champlain, Les voyages de Sieur de Champlain, 120.

43 Alison M. and David B. Quinn (eds), The English New England Voyages, 272. 


\section{THE TIMELESS AFRICAN AND THE VERSATILE INDIAN IN SEVENTEENTH-CENTURY TRAVELOGUES}

beginnings of permanent European settlement. The security and well being of countries such as France and England depended greatly on the number of skilled seamen it possessed because these accomplished sailors would be the ones recruited to man warships in the advent of conflicts. ${ }^{44}$ It follows than that a positive image of America and of its inhabitants would encourage settlement there and in turn would increase the number of sailors needed to carry these passengers. And the greater the voyages and the number of settlers to America would also stimulate the building of sailboats; the vessels that were crucial if a country was to colonize or exploit other parts of the world. Successful colonies in North America were particularly important to France and England since they badly trailed Portugal and Spain which already had a century of colonization behind them by the early 1600s. France and England also were distant second to the Netherlands in naval power. The Dutch were the uncontested leader on the seas at that time and could boast a flotilla of 15,000 vessels compared with the fleet of 6,000 boats that flew the British flag, and the 2,300 French ships that sailed the oceans. ${ }^{45}$

What is more, England and France were experiencing civil disorders in the late sixteenth and early seventeenth century, which made the success of their respective colonial projects in North America even more crucial. The religious hatred between Protestants and Catholics in England that stemmed (to some extent) from the uncertainty and inconstancy of the religious allegiances espoused by English monarchs at time of royal successions combined with the religious reformation that the country was undergoing, spurred the colonial expansion of England to the New World. A flourishing colony in North America could act as an outlet for a country that was overpopulated with a superfluous populace prone to religious conflicts. Edward Hayes, for example, thought England was "overburden and, as it were, pestered with people" in the early 1620 s. ${ }^{46}$

In France, the Catholic Reformation that strove to fight corruption in the Church and spread Catholicism worldwide was a prime motivation for seventeenth century French territorial expansionism. The zeal of secular and religious French colonists was remarkable. Champlain professed "the desire that I have always had to bring these people to God,"47 while a Jesuit priest confessed that "if there was a place on earth where I could suffer more, I would

44 Edward Lynam (ed), Richard Hakluyt \& His Successors (London: The Hakluyt Society, 1946), 15.

45 Philippe Bonnichon, Des cannibales aux castors: Les découvertes françaises de l'Amérique 1503-1788 (Paris: Les Éditions France-Empire, 1994), 174.

46 H.C. Porter. The Inconstant Savage: England and the North American Indian, 1500-1660 (London: Duckworth, 1979), 283.

47 Eltis, "Europeans and the Rise and Fall of African Slavery," 1400. 
go." 48 As a result of the push-and-pull factors bringing enthusiastic Dutch, French and British explorers, missionaries, and travelers to North America, most who wrote of their experiences there did so in overtly optimistic terms. For the majority, North America had the potential to be a paradise on earth. The apparent willingness of natives to welcome Europeans, the arrogant belief of Europeans to convert natives to Christianity, and the desire to escape retched conditions back home, played a part in the construct of the allegory of the benign native in that part of the world.

Alternatively, the European visitors to Africa who encountered a diseaseriddled environment and seemingly hostile natives not only nurtured age-old negative legends about Africans in Europe, but they also reproduced these same allegories until the end of the seventeenth century. The duplication of these images could be expected given that some who wrote of their so-called voyages to the African continents never even set foot there. P.H.E. Hair writes that there is no evidence that Olfert Dapper, for one, ever traveled outside Europe. ${ }^{49}$ Instead, the Dutch writer relied on existing sources to write his impressions of Africa and thereby joined a long list of European writers of imaginary travels with Richard Hakluyt and Samuel Purchas being amongst the more notable members of that class. As a result of the reliance of Europeans on previous travel documents, the same tropes about Africa and Africa were endlessly recurring in the travel literature of the period. For instance, the flatness of Africans' noses (purported to be the result of carrying children on the backs of their mothers as infants which caused their nose to break and flatten irrecoverably) was taken up successively by Jannequin, Villault, and Jacques-Joseph Lemaire over the span of forty years. ${ }^{50}$ In the same vein, the notion expressed in travelogues that all natives of the Ivory Coast were cannibals who filed their teeth for that very purpose, was propagated mainly by hearsay since there were no European forts in that region, and because the small number of visitors who did venture on the Coast did so but for a few short hours. ${ }^{51}$

The type of encounter that occurred between white travelers and African natives in the 1600 s also lent itself to a mindless repetition of predictable clichés about Africans. European ignorance about Africa and its local customs and languages persisted because contacts between Africans and Europeans were limited geographically and socially. The majority of the interaction occurred on board of European boats on or near the coast, and was very brief and limited to

48 de Brébeuf, Jean de Brébeuf, 80.

49 P.H.E. Hair, "Attitudes to Africans in English Primary Sources on Guinea up to 1650." History of Africa v. 26 1999, 33.

50 Claude Jannequin, Voyage de Lybie au Royaume de Sénéga (Paris: C. Rouillard, 1643), 92. Villault, Relations des Costes d'Afrique, 235. Jacques-Joseph Lemaire, Les Voyages aux Îles Canaries, Cap Vert, Sénégal et Guinée, (Paris: J. Collombert, 1682), 68. 


\section{THE TIMELESS AFRICAN AND THE VERSATILE INDIAN IN SEVENTEENTH-CENTURY TRAVELOGUES}

commercial transactions. Consequently, Europeans reproduced well-established "truths" about Africa in order to validate their own accounts. Needless to say, natives were powerless to end the propagation of African images in Europe given that Europeans held the monopoly over the written discourse on Africans. In these travelogues, natives were rarely portrayed as individuals and were spoken of by name even less. Rather, and in spite of the admission that Africa consisted of a variety of people and customs, Europeans wrote about African natives in general terms that had the effect of rendering them all equally inferior to Whites in what was considered a permanent situation. At the beginning of the century, the work of Leo Africanus provided a model for writers of narratives about Africa. ${ }^{52}$ In it he noted "[t]he Black continent is inhabited by men who live like beasts, without kings, lords, republics, governments, [and] customs." 53 Although the narrative about Africa changed little overtime - some images of Africa dated from Herodotus - it was by making the journey (either real or imaginary) that the writer acquired his authority, his legitimacy. Repetition served to further the alleged reality of the imagined Africans in an invented Africa.

In contrast with the situation in Africa, where the minimal interaction between Europeans and the native population led to the perpetuation of specific myths, changing circumstances that ensued from the prolonged presence of European settlers in North America gradually led to negative representations of the Indian in seventeenth-century travelogues. Despite the belief that natives could not be but impressed with the superior European civilization and would therefore willingly and eagerly want to adopt European mores, the goal of converting natives through osmosis, trade, and religion was a qualified accomplishment at best. The relationship between natives and colonists became increasingly complex in the course of the seventeenth century. The optimism of men like James Rosier who denoted "the exceeding good intention, quick understanding and readie capacity" of natives was replaced by a negative portrayal of natives in subsequent years. ${ }^{54}$ Writers increasingly painted all natives with the same "savage beast" brush often emphasizing among other things the native's delight (rather than the reluctance previously emphasized by Champlain and others) in "eat[ing] or rather devour[ing] raw flesh." 55 The rea-

51 Adam Jones, "Cannibales et Bon Sauvages: Stéréotypes Européens Concernant les Habitants de la Côte d'Ivoire, 1600-1750," dans Daniel Droixhe et Klaus H. Kiefer (éditeurs), Images de l'Africain de l'Antiquité au XIX $X^{e}$ Siècle (Paris: Verlag Peter Lang, 1987), 33.

52 Léon l'Africain was a well-traveled North African who made his way to Europe and who after having learned to write Latin wrote of his impressions of his native continent. His book was originally published in Latin in the mid-sixteenth century but was only translated in a number of European languages in the early 1600s.

53 Léon l'Africain, Description de l'Afrique, A. Épaulard, Th. Monod, H. Lhote et R. Mauray (éds) (Paris: Librairie d'Amérique et d'Orient Adrien Maisonneuve, 1956), 7:461.

54 Alison and David B. Quinn (eds), The English New England Voyages, 269.

55 Nathaniel Crouch, The English Empire in America (Dublin: S. Fuller, 1685), 13,74. 
son over the worsening description of the American Indian was that a dose of reality had doused European dreams of the North American earthly paradise over the years. Notwithstanding proclamations like that made by Jean de Brébeuf who believed that "universally speaking, they praise and approve of the Christian religion and blame their customs," it remains that, by his own admission, it took his religious congregation "seven years to convert the first healthy adult native in New France." 56 Colonists also grew increasingly frustrated with, and antagonistic toward, uncooperative natives like the Iroquois nations "who prevent us from enjoying the commodities of this country." 57 The failure to reconcile natives with the colonial cause was particularly dramatic in Virginia. The massacre of 347 settlers in and around Jamestown in 1622 was a sobering indication that the so-called superior English civilization was not enough in itself to win over natives to their way of life. ${ }^{58}$ Rather, the everincreasing presence of Europeans in North America, the intense competition over natural resources, and the periodic hostile reactions of the indigenous population protesting the theft of their ancestral lands, led to a growing antagonism between the intruders and native peoples. Europeans expressed the friction between themselves and the native population by stressing the savagery of the previously Noble Savage in travelogues.

The negative stereotyping of natives was accentuated not only by the disappointing lack of assimilation of the North American population to the so-called superior European way of life but also by the "Indianisation" of Europeans. The tendency of some Europeans to "go native" threatened the very foundation of the ideological construct upon which the colonial project rested. George Percy noticed that "many of our men ... did runn away unto the salvages ... willingly." 59 The dangers of Europeans embracing a native way of life to the colonial undertaking was dealt more explicitly by the Frenchman Denonville. In 1674, he shared his concerns with the Intendant of New France Colbert that "the example of the savages encourages the insubordination of our colonists." 60 The accultur-

56 de Brébeuf, Jean de Brébeuf, 11, 75.

57 Boucher, Histoire véritable et naturelle de la Nouvelle-France, 150. The Jesuit's allusion to the health of the baptized adult had to do with the custom of baptizing the dying native. This was done for two reasons. First, it was the only time that some natives relented and agreed to be converted in extremis since they figured they had little to lose. Secondly, it was because missionaries in New France were anxious to demonstrate their usefulness in the New World to their superiors and benefactors. They could thus inflate the numbers of "converted" Indians that were mostly made up of children in low age and dying adults. Numerous references to that method of acquiring a native flock are made in The Jesuit Relations and Related Documents edited by Reuben Thwaites at the turn of the twentieth century.

58 Mary C. Fuller, Voyages in Print: English Travel to America, 1576-1624 (Cambridge: Cambridge University Press, 1995), 92,101.

59 Ibid., 101.

60 Thérien (directeur), Les figures de l'Indien, 216. 


\section{THE TIMELESS AFRICAN AND THE VERSATILE INDIAN IN SEVENTEENTH-CENTURY TRAVELOGUES}

ation of Europeans to native customs also imperiled the raison d'être of the evangelizing mission in North America. It was feared that coureurs des bois who "live like beastly brutes, atheist and lustful, prevent the conversion and improvement of these poor people."61 Therefore, while Africa itself was the obstacle to European ambitions that led to its image of dark savagery, the obstacle in North America happened to be its native populations as the century progresses. It was only when natives in America (who had been portrayed as the lost children of humanity in early travelogues) stood in the way of European colonization that they were transformed into unredeemable savage beasts. And at that time, representations of native North Americans became eerily similar to descriptions of Africans found in seventeenth century travel literature.

If the exoticism of the journey gave Europeans the authority to judge Africa in Europe, in turn, the writers assumed the right to be there. Aside from the universal references to "our" Blacks found in travelogues, the sense of ownership-by-observation was vividly illustrated in Jobson's statement (when speaking about African gold) that "the earth hath shut up her rich bowels towards us in other places, the rather to invite us to seke after that, which lies as it were under our noses." 62 The same sentiment of European lordship over parts of Africa visited by them was also asserted by Barbot who wrote, "it is a great pity that they occupy [African natives] such a fine country."63 Yet, Europeans, for all their arrogance, still felt the need to justify their presence. This they did by using theoretical constructs disseminated in Europe by travel accounts which developed into "a master narrative that spoke for Africans." 64

The first means by which Europeans sought to legitimize their presence in Africa was to create an absolute dichotomy between themselves and the natives. The numerous references about the color of African in accounts of voyages were made to reinforce the idea that Blacks were un-European and therefore unequal. Thus, in addition to color as a symptom of inferior Otherness that had its shortcomings, writers of travel literature accentuated African phenomena as if they represented the norm rather than the exception. For example, the only drawing of an African in Barbot's travelogue is that of a deformed man with a "scrotum so enormously large as to be horrifying." 65

Another approach used in travel chronicles to portray Africans as the lesser Other in travel literature was to de-humanize them. The anthropophagy that was practiced in certain regions of Africa was portrayed as if it was endemic on

61 Ibid., 219.

62 Jobson, The Golden Trade, 2.

63 Barbot, Barbot on Guinea, 305.

64 Toni Morrison, Playing in the Dark: Whiteness and the Literary Imagination (Cambridge: Harvard University Press, 1992), 50.

65 Barbot, Barbot on Guinea, 271. 
the continent. Purchas wrote of the bad tendency of Africans in general of "eating each other."66 The indigenous population was also regularly compared to animals such as pigs, dogs, monkeys, wolves, and birds. And here, biblical references to man's lordship over beast could easily be correlated to the relationship between Europeans and African natives. Hence, the kidnapping or killing of local residents unwilling to trade, the pillage of villages in reprisal for failed commercial negotiations, and the beating of Africans caught stealing or bargaining in bad faith were sanitized in travel accounts. In Barbot's relation one could read that Africans were "like Spaniels, the more you beat them the more they love you."67

It followed that animal-like, cannibalistic Africans would also customarily enslave one another. The role of Europeans in the expansion of the trade in human beings was thus miraculously given a rational interpretation. Those who described slavery in Africa, did so as though the practice was a tradition that happened in a vacuum, as if it was organic to African societies. Vincent Le Blanc wrote that locals "sell their wife and kids on the local market."68 In return, Phillipo Pigaletta went even further in placing the onus for slavery on Africans themselves by portraying European participation as beneficial to slaves. He argued that Whites purchased black slaves otherwise they "deliver them to the butchers, to be cut in pieces, and so sold." 69 The Othering of Africa in seventeenth-century literature was an ideological construct that validated and minimized the negative impact of the presence of Europeans on the west coast of Africa and their participation in the slave trade.

In North America, the European civilizing mission of natives was doomed from the beginning because colonizers wrongly "assumed the existence of a cultural dichotomy between the savage and the civilized."70 Otherwise stated, European civilization was the measure by which the Indian was gauged by colonists who were eager to replicate their society in the North America since it was presumed that theirs was the superior one. As a result, anything that was deemed un-European behavior amongst native tribes was especially vilified in travel relations. Since order in European society was based on subordination and social control, nomadic tribes who continued to flaunt their independence from European authorities were prime targets for writers of travel literature. Champlain, in one of his later chronicles, stated his disgust of "savages who

66 Samuel Purchas, Purchas his Pilgrimage, or, Relations of the World and the Religions Observed in All Ages and Places (Glasgow: James Maclehose \& Sons, 1905), 6:386.

67 Barbot, 487.

68 Vincent La Blanc, Les Voyages Fameux de ... aux Quatres Parties de Monde .... (Paris: G. Clousier, 1648), 2:4.

69 In Purchas, Purchas his Pilgrimage, 6:427.

70 Olivia Patricia Dickason, Le mythe du sauvage (Sillery: Les Éditions du Septentrion, 1993), 290. 


\section{THE TIMELESS AFRICAN AND THE VERSATILE INDIAN IN SEVENTEENTH-CENTURY TRAVELOGUES}

have no permanent settlement [who] roam the countryside like wild animals."71 In addition, native medicine men who did not pray to the "right" God were said to be instead "invocators of the Devil."72 Furthermore, Indian clothing was not considered clothing because it was unlike anything Europeans were accustomed to. English colonists like Gabriel Archer thought of them as to be "all but naked." 73 In the same vein, women whose sexual conduct and role within marriage unions did not conform with a Christian moral code were essentialised as whores, while natives were thought to possess no laws but simply customs because they did not have governments similar to those operating in Europe. $^{74}$

Although Indian culture was considered inferior to European civilization, that is not to say that these assumptions were based on some sort of racial hierarchy. On the contrary, North American natives were often judged favorably in comparison with Europeans of lower classes. Boucher remarked "it is very rare to see dense and uncouth sorts amongst them like we can in France amongst our peasants."75 The English aristocrat Sir Fernand Georges also pointed out that natives "shewed great civility farre from the rudeness of our common peoplee."76

Rather, the gradual appreciation of local mores in travelogues of North America in the latter part of the seventeenth century was made possible by the knowledge that Europeans acquired overtime. Some began to address the misconceptions about the uncivilized Indian that were based on misunderstandings, prejudices, or motivated by political considerations. The Englishman Robert Beverly set out to debunk many of the myths that were propagated about the indigenous population of Virginia. In The History and Present State of Virginia he wrote that the idea that all native women were prostitutes was "an unjust scandal upon them," that the native practice to paint their bodies was not a savage custom but a way of different tribes to "distinguish themselves" (in the

71 Samuel de Champlain, Voyages to New France... being an account... of the remarkable things that happened in the years 1615 to 1618, translated by Michael Macklem (Toronto: Orebon Press, 1970), 81.

72 Sagard, Le grand voyage du pays des Hurons, 269.

73 Alison M. and David B. Quinn (eds), The English New England Voyages, 117. In the seventeenth century, clothing in Europe was a visual sign of social status and was enforced by sumptuary laws. Little wonder than that the first preoccupation of European colonists throughout the world and well until into the twentieth century - was to encourage (either amiably or forcefully) natives to wear "civilized" clothing as a means to control the population where a European social power structure could thus be reproduced. For more on this issue in relation to the seventeenth century see Gordon Sayre. Les Sauvages Américains. Chapel Hill: The University of North Carolina Press, 1997, $124-167$.

74 de Champlain, Voyages to New France, 98.

75 Boucher, Histoire véritable et naturelle, 96.

76 In Alison M. and David B. Quinn (eds), The English New England Voyages, 340. 
same manner that dress code operated as a social distinction in Europe), and that the so-called idleness of local peoples was not a cultural shortcoming but was preferable to the "curse of labor." 77 This last observation also bridged the gap between the appreciation of native culture and the critique of European society based on native ideals.

The most famous of these criticisms of seventeenth-century European society by way of the native was Louis Armand Lahontan's famous Dialogue. The use of the North American Indian to criticize particular European civilizations by some Europeans led to the image of the Noble Savage in travel accounts written in the latter part of the seventeenth century. The conversation recorded between Adario and Lahontan himself expressed the ambivalence of some Europeans who were told (in travel literature) that native culture was inherently inferior to their own. In his book, Lahontan used the native Adario to criticize the religious intolerance of Christian Europeans. Adario remarked that "although yours is different than ours, that does not mean that we don't have any at all."78 The native Chief also noted that the bible was made up of "so much reveries." 79 Lahontan sarcastically referred to Eurocentric notions of the "nakedness" of natives in contrast with the "civility" of Europe as well when Adario was said to have remarked that French women "show their breasts to all" while "savage women hides them." 80

In contrast, the disparate nature of interaction between Europeans and local populations explains the absence of the Noble Savage in Africa. No European traveler to Africa in the seventeenth century could equal the knowledge acquired by Nicolas Denys who wrote "it has been thirty seven, thirty eight years that I am in this country." 81 And it was because of the transitory character of the contact between themselves and the natives in Africa that European writers - unlike those voyaging to North America at the time - failed to observe (over a long period), learn about, and gain an appreciation of local societies. Given the influence of native culture on European visitors to North America, it seems more than probable that African customs would have had the same impact - and the image of the African been more positive - if European presence there had occurred under similar circumstances to those which prevailed across the Atlantic Ocean.

77 Robert Beverly, The History and Present State of Virginia (Indianapolis: The Bobbs-Merrill Company Inc., 1971), 96, 100, 118.

78 Lahontan. Oeuvres complètes, 803.

79 Ibid. 806.

80 Ibid. 879.

81 Nicolas Denys, Histoire naturelle des peuples, des animaux, des arbres, \& des plantes de l'Amérique septentrionale (Paris: Chez Claude Barbin, 1672), 336. 


\section{THE TIMELESS AFRICAN AND THE VERSATILE INDIAN IN SEVENTEENTH-CENTURY TRAVELOGUES}

By way of conclusion, a couple of examples permit us to envision that the image of the natives of Africa and North America in seventeenth-century travel literature would have been highly similar under analogous conditions. Brief passages found in chronicles on Africa praised local traders who were receptive to European merchants and others natives who were thought to emulate European-like behavior. Friendly African traders were transformed into "much more civilized" human beings or were described as "clean" (amazingly so given the association of blackness with dirtiness in European at the time) when European merchants profited from their transactions. ${ }^{82}$ The positive terms used to describe industrious men who were hospitable while conducting business transactions with European merchants were also ascribed to native women who fitted existing conceptions of women among European males. Dapper was especially delighted by the women of particular traders who allegedly kept water in their mouths all morning in order to keep silent while they did house chores. ${ }^{83}$ Yet, these instances of positive depictions of African natives did not overcome the overall negative views on Africans, nor did it lead to the materialization of an African Adario in seventeenth-century travelogues.

A final illustration of the primacy of familiarity over racial gradation or prejudice to explain the more favorable image of the Indian is found in the evolving image of the Khoikhoi of South Africa. Their representation underwent transformations that were eerily similar to that of native North American Indians. Indeed, that South African society remained free, enjoyed good relations, and was highly praised in the correspondence of eighteenth-century Dutch officials. That situation prevailed as long as the latter depended on the former to live in South Africa. ${ }^{84}$ The vilification of the indigenous population in reports from the Dutch colony coincided with the intrusion on Khoikhoi lands by Boer colonists. From that time onward, the Khoikhoi were deemed especially "savage," "beast-like" and considered an impediment to civilization by Boer settlers. ${ }^{85}$ The resemblance in the evolving negative image of natives and in its timing in America and South Africa, supports the idea that representations of the non-European Other had little to do with a racially-based pecking

82 Villault, Relations des Costes d'Afrique, 108. Olfert Dapper, Description de l'Afrique... (Amsterdam: Chez Wolfgang, Waesberge, Boom et van Someren, 1686), 231. The positive description of African natives by these two authors were highly exceptional not only in travel literature throughout the seventeenth century, but also in their own works which overwhelmingly portrayed natives in a negative light.

83 Dapper, Description de l'Afrique, 152.

84 The temperate climate of South Africa - as opposed to the tropical environment of the subSaharan region - is similar to that of Europe and was the site of the first substantial European settlement on the continent.

85 Richard Elphick and Hermann Giliomee (eds.), The Shaping of South African Society, 16521820. (Cape Town: Longman Penguin Southern Africa Ltd, 1979), 7-19. 
order. The numerous affinities (in the colonial settings of South Africa and North America) and disparities (the lack of interaction in West Africa and the extensive relations on the Eastern coast of North America) in the representation of African and North American natives in seventeenth-century chronicles of voyages fly in the face of any notions that a racially-inspired European standard played a part in the different images of the African and Indian in these writings.

The acknowledgment that European writers of travel accounts did not operate in a vacuum - that their knowledge or lack thereof influenced their description of natives - can give a new perspective which recognizes that it was the North American natives themselves who largely influenced the change in the metaphors used by Europeans to describe them in seventeenth-century travel documents. European immigrants coming to this continent (either temporarily or permanently) were able, overtime and however falteringly, to learn hitherto incomprehensible native languages, cultures, and individuals. Towards the end of the century, some chroniclers even questioned not only their society in face of European questionable practices in North America, but also appreciated native culture for what it was after having observed "Noble" Savages for months, years, and even decades. There is little doubt that, in spite of the othering of the "inferior" native in seventeenth century literature, the interaction between Europeans and North American natives produced a symbiosis that was not governed by existing power relations. James Axtell writes that natives, facing diseases, war, and dislocation managed to convert hundreds of colonists to a native way of life in New England. ${ }^{86}$ In Africa on the other hand, images of the Dark Continent and its black savages remained a fixture in travel literature throughout this period on account of the sustained lack of knowledge of local languages, mores, and societies. Stressing the role of natives in influencing the representations of themselves in travel accounts does not negate the mental evolution of European writers in the seventeenth century. After all, native culture was criticized to justify European intervention in Africa and North America, to prove the superiority of European civilization, or was praised by European travelers to pass judgment on their own decadent society or that of other European rivals. Yet, in the end, firsthand knowledge rather than preconceptions explained the different images of the African and the North American Indian in seventeenth-century travelogues.

86 James Axtell. The Invasion Within: The Contest of Cultures in Colonial North America (New York: Oxford University Press, 1985), 5. 